\title{
Synthesis, stability, and crystal structure of an azulenium cation containing an adamantyl group
}

\author{
Mitsunori Oda, ${ }^{*[a]}$ Nobue Nakajima, ${ }^{[b]}$ Nguyen Chung Thanh, ${ }^{[b]}$ Kazuhiro Kitahara, ${ }^{[a]}$ Ryuta \\ Miyatake, ${ }^{[b]}$ and Shigeyasu Kuroda ${ }^{[b]}$
}

Keywords: Carbocations / Spiro compounds / Nazarov cyclizations / $\mathrm{pK}_{\mathrm{R}}+$ values / X-ray crystallographic structures

Starting from trimethylsilyl enol ether of 1-acetyl-1,3,5cycloheptatriene, the title $1 \mathrm{H}$-azulenium cation was synthesized by a five-step sequence that involves the Noyori-Mukaiyama aldol reaction, the Nazarov cyclization, the Shapiro reaction, and hydride abstraction. The Nazarov reaction of the aldol-type adduct resulted in formation of an unusual double-bond position isomer, which has never been obtained in similar reactions forming tetrahydro- azulenones. The $\mathrm{p} K_{\mathrm{R}}+$ value of the title cation was found to be 9.8 , which is less than that expected by inductive stabilization of the carbon number at the 1-position. The $\mathrm{X}$-ray crystal structure of the title cation $\left(\mathrm{ClO}_{4}^{-}\right.$salt $)$reveals $\mathrm{CH}-\mathrm{O}$ interactions and deformation of the azulenyl ion part.

(C) WILEY-VCH Verlag GmbH \& Co. KGaA, 69451 Weinheim, Germany, 2007)

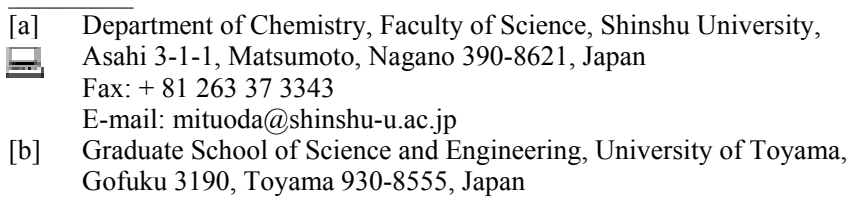

\section{Introduction}

The tropylium cation (1) has played an important role in the historical development of positively charged Huckeloid aromatic systems. $^{[1,2]}$ Stability of cyclic $\pi$-conjugated carbocations, particularly shown as $\mathrm{pK}_{\mathrm{R}}+$ values, aids in understanding the capability of $\pi$-conjugation and the outcome of various structural effects on delocalized carbocations. We previously reported the syntheses of various 1,1-spiroalkylated $1 H$-azulenium cations 2 $\mathbf{6}^{[3,4]}$ and 1,1-dialkylated $1 \mathrm{H}$-azulenium cations 7-9 $\mathbf{9}^{[5]}$ (Figure. 1). Their $\mathrm{p} K_{\mathrm{R}}+$ values were in the range of 8.6-13.2, which are far greater than that $(3.9)^{[6]}$ of $\mathbf{1}$. The enhanced thermodynamic stability is attributable to the stabilization of both the inductive and $\sigma-\pi$ conjugation effects of the exocyclic ring at the 1-position and the $\pi-\pi$ conjugation of the double bond at the 2,3-positions. The order of stability of the mono-spiroalkylated cations increases with the number of carbon atoms of the exocyclic ring, as $\mathbf{2}<\mathbf{3}<\mathbf{4}^{[3]}$ On the other hand, the order of stability of the dialkylated cations does not correspond with the number of carbon atoms of the alkyl groups at the 1-position, as $7<\mathbf{9}<\mathbf{8} .{ }^{[5]}$ Since the degree of the $\pi-\pi$ conjugation effect is the same in a series of the cations, the order of stability of these cations should also correspond to the degree of the effects of the substituents at the 1-position; i.e. the cations having more carbon atoms in the substituents at the 1-position should be more stable, although the effects may saturate at some large number of carbon atoms. The reason of the stability of 7-9, which is not compatible with the order of the number of carbon atoms in the alkyl groups, may be ascribed to the relative difficulty of solvation of 9 due to congestion around the 1-position by two slightly bulkier propyl groups. Therefore, it is thought that for increasing the stability of 1,1-substituted azulenium cations by an inductive effect, introduction of a compact substituent with a larger number of carbon atoms is required. Considering this, we designed the azulenium cation $\mathbf{1 0}$ containing an adamantyl group constructed with ten carbon atoms. In this paper, we describe its synthesis, stability, and X-ray structural analysis.

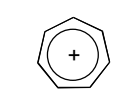

Tropylium ion 1

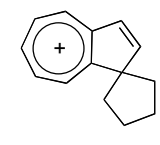

2

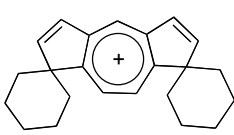

5

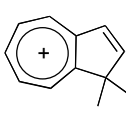

7

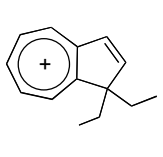

8

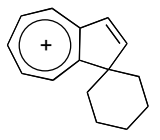

3

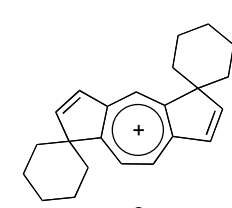

6

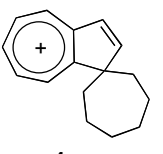

4
Figure 1. Tropylium and azulenium ions with various spiro-carbocycles.

\section{Results and Discussion}

The title cation was synthesized by the method, which we had developed for synthesizing spiroalkylated cation $\mathbf{3}$ and $\mathbf{4}$ (Scheme 1). ${ }^{[3 b, 5,7]}$ The Noyori-Mukaiyama aldol reaction ${ }^{[8]}$ of the trimethylsilyl enol ether 11 with 2,2-dimethoxyadamantane in the presence of trimethylsilyl triflate gave 12 in $44 \%$ yield. The subsequent Nazarov cyclization ${ }^{[9,10]}$ provided the azulenones $\mathbf{1 3}$ in $50 \%$ yield. The azulenone 13 was transformed into the 1,4dihydroazulene 14 via the tosylhydrazone of $\mathbf{1 3}$ by the Shapiro reaction. ${ }^{[11]}$ A final hydride abstraction of $\mathbf{1 4}$ with trityl perchlorate resulted in the desired cation $\mathbf{1 0}$ as yellowish brown crystals. The structure of $\mathbf{1 0}$ was characterized by spectroscopic and combustion 
OTMS

11
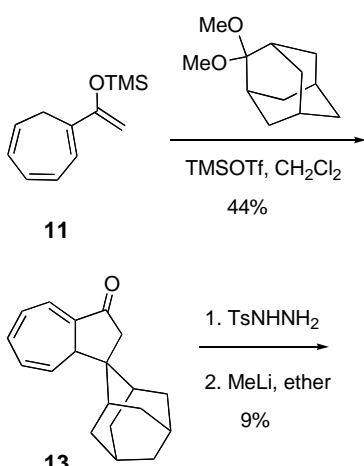

$44 \%$

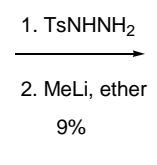

$9 \%$

Scheme 1. Synthesis of $\mathbf{1 0}$

analyses. Signals except undissolved hydrogens in the ${ }^{1} \mathrm{H}$ NMR spectrum of $\mathbf{1 0}$ were assigned by analysis of $\mathrm{H}-\mathrm{H}$ COSY and NOE experiments (Figure 2). Chemical shifts of olefinic protons of $\mathbf{1 0}$ along with those of $\mathbf{2 , 3}$ and $\mathbf{4}$ are listed in Table 1 . The protons at the 2- and 8-positions of $\mathbf{1 0}$ resonate at a lower magnetic field compared with the corresponding protons of $\mathbf{2}, \mathbf{3}$ and $\mathbf{4}$. In addition, axial $\mathrm{H} a$ and $\mathrm{H} b$ of the adamantyl group show a similar tendency compared with hydrogens of the exocyclic ring in 12, 13, and 14, suggesting a steric compression effect ${ }^{[12]}$ between $\mathrm{Ha}$ and $\mathrm{H}-2$ hydrogens and between $\mathrm{H} b$ and $\mathrm{H}-8$ hydrogens. Their UV spectra showed three bands at 224, 246, and $367 \mathrm{~nm}$ as seen in the spectra of 2-4 and $\mathrm{pH}$ dependent absorptions of the third band were applied for its $\mathrm{p} K_{\mathrm{R}}+$ measurement (vide ínfra).
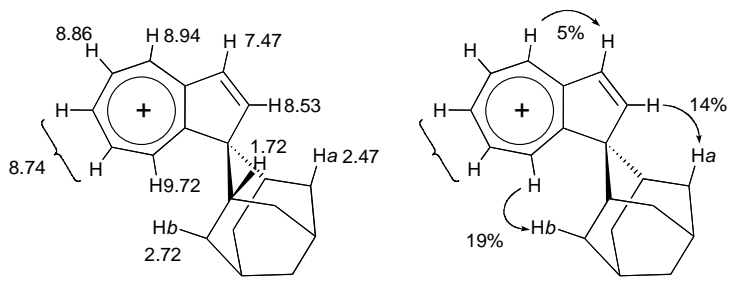

Figure 2. Proton chemical shifts $\left(\delta_{\mathrm{ppm}}\right)$ in $\mathrm{CD}_{3} \mathrm{CN}$ of $\mathbf{1 0}$ (left) and the result of NOE experiments (right).

Table 1. Chemical shifts $\left(\delta_{\mathrm{ppm}}\right)$ of olefinic protons of cations $\mathbf{2}, \mathbf{3}, \mathbf{4}$, and $\mathbf{1 0}$ in $\mathrm{CD}_{3} \mathrm{CN}$

\begin{tabular}{llllllll}
\hline cations & $\mathrm{H}-2$ & $\mathrm{H}-3$ & $\mathrm{H}-4$ & $\mathrm{H}-5$ & $\mathrm{H}-6$ & $\mathrm{H}-7$ & $\mathrm{H}-8$ \\
\hline $\mathbf{2}^{\text {[a] }}$ & 7.72 & 7.33 & 8.96 & 8.90 & 8.75 & 8.77 & 9.00 \\
$\mathbf{3}^{\text {[a] }}$ & 8.13 & 7.49 & 9.12 & 9.00 & 8.85 & 9.01 & 9.10 \\
$\mathbf{4}^{\text {a] }}$ & 8.00 & 7.42 & 8.99 & 8.90 & 8.74 & 8.82 & 9.07 \\
$\mathbf{1 0}$ & $\mathbf{8 . 5 3}$ & 7.47 & 8.94 & 8.86 & 8.74 & 8.74 & $\mathbf{9 . 7 2}$ \\
\hline
\end{tabular}

[a] Data taken from Ref. 3b.

Note that the structure of $\mathbf{1 3}$ is unusual; cyclizations of various cycloheptatrienylethanones $\mathbf{1 5}$ under the same reaction conditions yielded 1,2,3,8-tetrahydroazulen-1-ones instead of the 1,2,3,3aisomer 16 (Scheme 2) ${ }^{[3,4,5,7]}$ Since the Nazarov cyclization is believed to proceed through $4 \pi$-conrotatory electrocyclization of a protonated intermediate $\mathbf{1 8},{ }^{[10,13]}$ the key process for giving a different product is the deprotonation step of the oxyallyl cation intermediate 19 (Scheme 3). The unusual formation of 13 (22) in

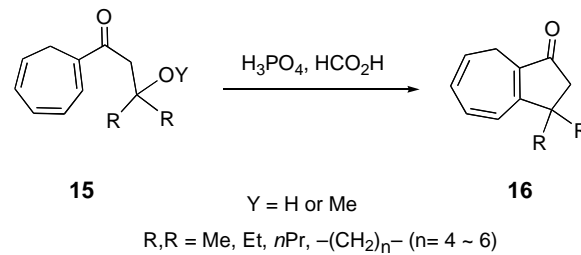

Scheme 2. Nazarov cyclization of $\mathbf{1 5}$.

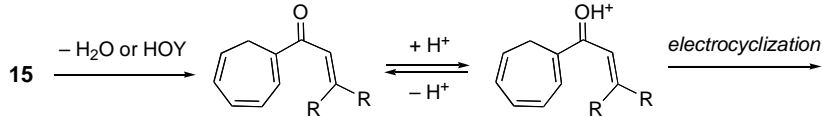

17

18

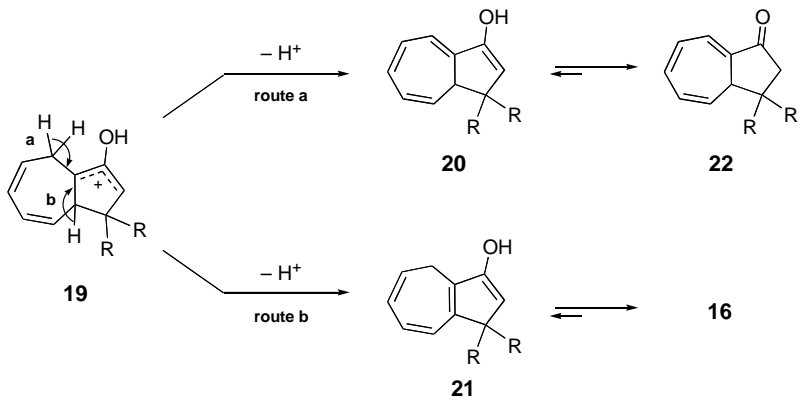

Scheme 3. Possible reaction paths for Nazarov cyclization.

this study is rationalized based on density functional theory (DFT) calculations $^{[14]}$ of possible enol intermediates, 20 and 21, as follows. Calculations at B3LYP/6-31G(d) level of theory predict that the enol $\mathbf{2 0}$ is more stable than $\mathbf{2 1}$ for the adamantaneconnected system, whereas the enol $\mathbf{2 0}$ is less stable than $\mathbf{2 1}$ for the cyclohexane-connected system (Figure 3). The inversed energy difference for the adamatyl system is mainly due to short atomic distances (192.3 and $211.5 \mathrm{pm}$ ) between the hydrogen at the 8position of the azulenyl part and hydrogens at the adamantyl group in 21. Besides the theoretical study, approach of either the solvent molecule or its conjugate base for deprotonation of H-8a from 19 is thought to suffer from steric repulsion with the adjacent methylene protons at the adamantyl group, judging from the Dreiding model study. In fact, congestion around the hydrogen atom at the 8aposition is also seen in the reaction rate of hydride abstraction of 14; while the reactions of 1,4-dihydroazulenes with trityl cation complete within $1 \mathrm{~h}$ at room temperature, the reaction of $\mathbf{1 4}$ requires $17 \mathrm{~h}$ at $55^{\circ} \mathrm{C}$.
Cyclohexane-connected enol

20

(3.23)

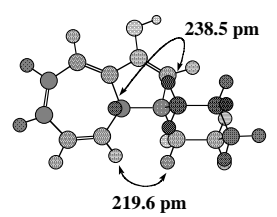

21

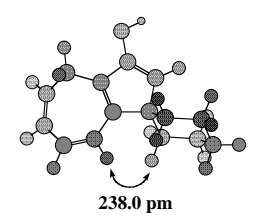

Adamantane-connected enol
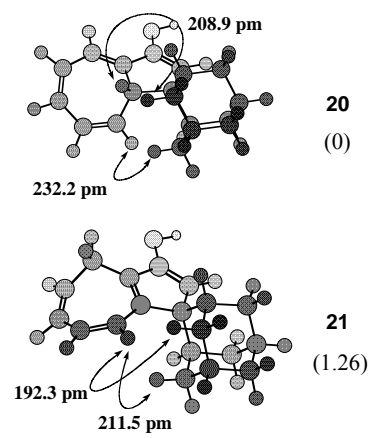

Figure 3. Enol intermediates calculated by the B3LYP/6-31G(d) level of theory. Values in parentheses are relative total energies $\left(\mathrm{kcal} \mathrm{mol}^{-1}\right)$. 
Assuming equilibrium between a carbocation and its corresponding alcohol (Eq. (1)), the $\mathrm{p} K_{\mathrm{R}}+$ value, which indicates thermodynamic stability for the carbocations, can be determined. ${ }^{\text {a }}$

$$
\mathbf{R}^{+}+\mathrm{H}_{2} \mathrm{O} \rightleftharpoons \mathrm{ROH}+\mathrm{H}^{+}
$$

The $\mathrm{p} K_{\mathrm{R}}+$ value of $\mathbf{1 0}$ was determined to be 9.8 by the UV method in $50 \%$ aqueous acetonitrile solutions. The thermodynamic stability of $\mathbf{1 0}$ is greater than that of the tropylium cation $(\mathbf{1}),{ }^{[6]}$ and is comparable to those of cations $\mathbf{2}$ and $\mathbf{3}$. The reduction potential of carbocations indicates their reluctance for reduction and provides another empirical stability parameter for carbocations. ${ }^{[15]}$ Reduction potentials for various azulenium ions measured by cyclic voltammetry along with $\mathrm{p} K_{\mathrm{R}}+$ values are shown in Table 2 . The reduction potential of $\mathbf{1 0}$ is greater than $\mathbf{2}$ and $\mathbf{3}$, and is the same as that of 4 . Both the $\mathrm{p} K_{\mathrm{R}}+$ value and the reduction potential

Table 2. $\mathrm{p} K_{\mathrm{R}}+$ values and reduction potentials of $\mathbf{2 - 4}, \mathbf{7 - 9}$, and $\mathbf{1 0}$

\begin{tabular}{ccc}
\hline Cations & $\begin{array}{c}\mathrm{pK}_{\mathrm{R}}{ }^{+} \\
\text {value }^{[\mathrm{a}]}\end{array}$ & $\begin{array}{c}\text { Reduction potentials } \\
(\mathrm{V} v \text { vs SCE })^{[\mathrm{b}]}\end{array}$ \\
\hline $\mathbf{2}^{[\mathrm{c}]}$ & 9.9 & -0.41 \\
$\mathbf{3}^{[\mathrm{cc}]}$ & 10.0 & -0.46 \\
$\mathbf{4}^{[\mathrm{c}]}$ & 10.4 & -0.54 \\
$\mathbf{7}^{[\mathrm{d}]}$ & 8.6 & -0.38 \\
$\mathbf{8}^{[\mathrm{d}]}$ & 10.1 & -0.45 \\
$\mathbf{9}^{[\mathrm{d}]}$ & 9.2 & -0.46 \\
$\mathbf{1 0}^{[\mathrm{e}]}$ & $\mathbf{9 . 8}$ & $\mathbf{- 0 . 5 4}$
\end{tabular}

[a] For measurements, see experiments. [b] Irreversible. [c] Taken from Ref 3b. [d] Taken from Ref 5. [e] This study.

of $\mathbf{1 0}$ are less than that expected by inductive stabilization of the nine carbon atoms at the 1-position. It is thought to be difficult for the adamantyl group to accumulate the inductive effect because of the intricate structural nature. Besides ineffective solvation due to congestion around the carbon atom of the 1-position can be the reason still in the case of $\mathbf{1 0}$, as suggested for $\mathbf{9}^{[5]}$ In order to obtain further structural information on the perchlorate salt of $\mathbf{1 0}$, we examined its X-ray crystallographic analysis.

Yellowish prismatic crystals of the perchlorate salt of $\mathbf{1 0}$ were obtained by recrystallization from a mixture of $n$-hexane and dichloromethane. ORTEP drawings and the crystal packing of $\mathbf{1 0}$ are shown in Figure 4. The $\mathrm{C}-\mathrm{C}$ bond lengths of the azulenyl part are comparable to those of $\mathbf{3}$ (Figure 5). ${ }^{[\mathrm{b}]}$ Bond alternation of the seven-membered ring is as small as that of 3 . Slightly longer $\mathrm{C}-\mathrm{C}$ bond lengths (157.2 and $156.7 \mathrm{pm})$ at the $\mathrm{Cl}^{\prime}(\mathrm{C} 1)$ of the adamantyl group imply $\sigma-\pi$ conjugation, as seen in 3 . The azulenyl part of the crystal structure is non-planar, and the adamantyl group is not symmetric against the azulenyl plane. Deviation of carbon atoms of the azulenyl part from its mean plane is also shown in Figure 5. The average of the deviation is $4.62 \mathrm{pm}$, which is greater than that of $3(1.15 \text { and } 1.34 \mathrm{pm})^{[3 \mathrm{~b}]}$ and $5(0.41 \mathrm{pm}),{ }^{[3 \mathrm{~d}, \mathrm{e}]}$ indicating clear deformation of the azulenyl ring. Since this cation molecule has the same atom arrangement at both up and down sides of the azulenyl plane, and there is sufficient space for the plane to spread in the crystal cell as seen in its packing, the deformation of the azulenyl plane can be ascribed neither to the steric congestion between $\mathrm{H}-2$ and $\mathrm{Ha}$ hydrogens and between $\mathrm{H}-8$ and $\mathrm{H} b$ hydrogens nor to the packing of the azulenyl part in the cell. Distances between perchlorate oxygen atoms with $\mathrm{H}-2$ and $\mathrm{H}-4$ hydrogen atoms are found to be in the range of $238.1-259.3 \mathrm{pm}$, which are sufficiently short to suggest $\mathrm{CH}-\mathrm{O}$ interactions. Thus, the deformation is rather considered to be derived from these interactions, and it is assumed
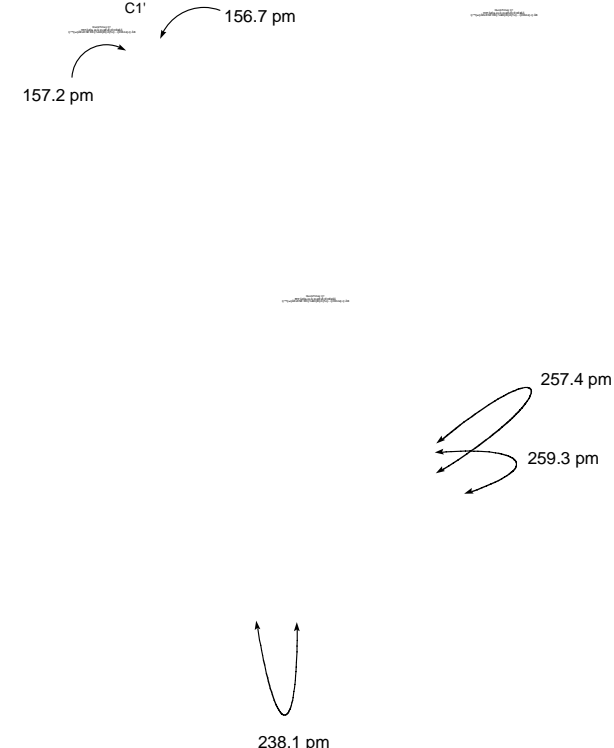

Figure 4. Crystal packing and ORTEP drawings of $\mathbf{1 0}$
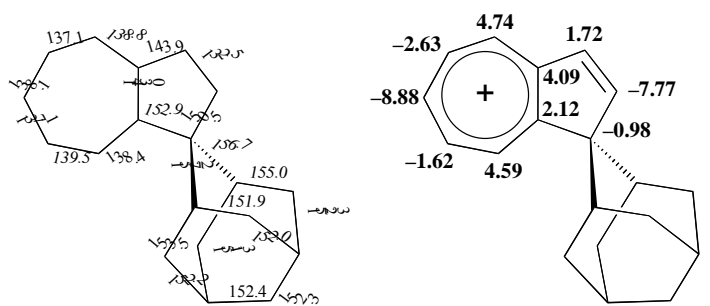

Figure 5. Bond lengths (in pm, left) of $\mathbf{1 0}$ and deviations (in pm, right) of the azulenyl carbons from its mean plane.

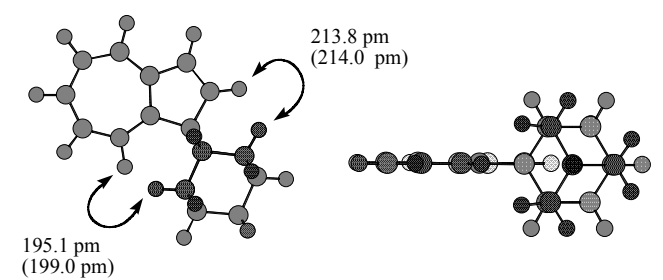

Figure 6. Optimized structure (Chem3D output) of cation $\mathbf{1 0}$ and atomic distances. Values for X-ray analysis are shown in parentheses.

that $\mathbf{1 0}$ should have a planar azulenyl part in a solution or a gas phase, unlike the crystal structure. DFT calculations of cation $\mathbf{1 0}$ indeed predict a planar structure (Figure 6), though the structure shows short atomic distances between the azulenyl 2,8-hydrogens and the adamantyl $\mathrm{Ha}$ and $\mathrm{H} b$ hydrogens. The X-ray and theoretical structures support the crowding atom arrangement and the steric compression shift in the ${ }^{1} \mathrm{H}$ NMR spectrum. The average distances between $\mathrm{H} a$ and $\mathrm{H}-2$ hydrogens and between $\mathrm{H} b$ and $\mathrm{H}-8$ hydrogens in the crystal structure are 214.0 and $199.0 \mathrm{pm}$, respectively. 


\section{Conclusions}

We have applied the previously developed methodolgy for azulenium cations to the synthesis of the novel azulenium ion $\mathbf{1 0}$. The Nazarov reaction of aldol-type adduct $\mathbf{1 2}$ provided an $\mathrm{C}-\mathrm{C}$ double bond position isomer 13, which has never been obtained in similar reactions forming other tetrahydroazulenones. The formation of $\mathbf{1 3}$ was discussed based on DFT calculations of enol intermediates. The ${ }^{1} \mathrm{H}$ NMR spectrum of $\mathbf{1 0}$ showed a clear steric compression effect between $\mathrm{H} a$ and $\mathrm{H}-2$ hydrogens and between $\mathrm{H} b$ and $\mathrm{H}-8$ hydrogens. The $\mathrm{p} K_{\mathrm{R}}+$ value of $\mathbf{1 0}$ was determined to be 9.8 , which is less than that expected by inductive stabilization of the carbon numbers of the exocyclic rings at the 1-position. The Xray crystal structure of the perchlorate salt of $\mathbf{1 0}$ reveals $\mathrm{CH}-\mathrm{O}$ interactions and deformation of the azulenium ion part.

\section{Experimental Section}

General Remarks: Melting points were measured on a Yanaco MP-3 and are uncorrected. IR spectra were recorded on a PerkinElmer Spectrum RX I spectrometer. UV spectra were measured on a Shimadzu UV1600 spectrometer. ${ }^{1} \mathrm{H}$ - and ${ }^{13} \mathrm{C}-\mathrm{NMR}$ were recorded with tetramethylsilane as internal standard on a JEOL $\alpha 400$ spectrometer. Mass spectra were measured on a JMS-700 mass spectrometer. Cyclic voltammograms were recorded on a Yanaco P11000 instrument. Column chromatography was performed with Merck Kieselgel 60 Art 7743 or Wako activated alumina. Ether was purified from sodium and benzophenone by distillation under an argon atmosphere. An ether solution of methyl lithium was purchased from Kanto Chem. Co., and was titrated before use. Trimethylsilyl triflate was purchased from Tokyo Chemical Industry, Inc. The synthesis of $\mathbf{1 1}$ was previously reported. ${ }^{[7]}$ Trityl perchlorate was prepared by the method of Dauben et al. ${ }^{[16]}$

Synthesis of 1-(cyclohepta-1,3,5-trienyl)-2-(2-methoxyadamant2-yl)ethanone (12): A solution of $92 \mu \mathrm{l}(50.0 \mathrm{mmol})$ of trimethylsilyl triflate was added dropwise to a solution of $1.03 \mathrm{~g}$ $(5.00 \mathrm{mmol})$ of the silyl enol ether 11 and $0.981 \mathrm{~g}(5.50 \mathrm{mmol})$ of 2,2-dimethoxyadamantane ${ }^{17}$ in $25 \mathrm{ml}$ of dichloromethane at $-78^{\circ} \mathrm{C}$ under nitrogen atmosphere. After being stirred for $12 \mathrm{~h}$, the reaction mixture was poured into $50 \mathrm{ml}$ of ice-water. The aqueous layer was extracted with dichloromethane $(50 \mathrm{ml} \times 2)$. The combined organic layer was washed with a saturated $\mathrm{NaHCO}_{3}$ aqueous solution and brine, and then dried over anhydrous $\mathrm{MgSO}_{4}$. The solvent was removed under reduced pressure, and the residue was purified by column chromatography $\left(\mathrm{SiO}_{2}, 3 \%\right.$ ethyl acetate in hexane as eluent) to give $0.659 \mathrm{~g}$ (44\% yield) of $\mathbf{1 2}$ as pale yellow solids. $\mathrm{Mp}=81-82^{\circ} \mathrm{C} .{ }^{1} \mathrm{H}$ NMR $\left(\mathrm{CDCl}_{3}\right) \delta 1.49(\mathrm{dm}, J=12.0 \mathrm{~Hz}$, $2 \mathrm{H}), 1.69$ (brs, 2H), 1.76-1.79 (m, 3H), 1.86-1.89 (m, 3H), 2.11$2.13(\mathrm{~m}, 4 \mathrm{H}), 2.65(\mathrm{~d}, J=7.1 \mathrm{~Hz}, 2 \mathrm{H}), 3.09(\mathrm{~s}, 2 \mathrm{H}), 3.16(\mathrm{~s}, 3 \mathrm{H})$, $5.57(\mathrm{dt}, J=9.2,7.1 \mathrm{~Hz}, 1 \mathrm{H}), 6.25(\mathrm{dd}, J=9.2,5.8 \mathrm{~Hz}, 1 \mathrm{H}), 6.69$ (dd, $J=10.9,6.0 \mathrm{~Hz}, 1 \mathrm{H}), 6.83(\mathrm{dd}, J=10.9,5.8 \mathrm{~Hz}, 1 \mathrm{H}), 7.07$ (d, $J=6.0 \mathrm{~Hz}, 1 \mathrm{H}) \mathrm{ppm} ;{ }^{13} \mathrm{C} \mathrm{NMR}\left(\mathrm{CDCl}_{3}\right) 26.1,27.0,27.4,32.7$, 34.5, 34.6, 38.3, 39.1, 48.4, 80.2, 125.9, 126.9, 129.0, 131.1, 133.7, $135.5,198.9 \mathrm{ppm}$; IR $(\mathrm{KBr}) v_{\max }=2910 \mathrm{~s}, 2860 \mathrm{~m}, 1645 \mathrm{~s}, 1162 \mathrm{~m}$ $\mathrm{cm}^{-1}$; MS (70 eV) m/z (rel int) $298\left(\mathrm{M}^{+}, 1\right), 266(17), 165(35), 122$ (12), 119 (20), 118 (100), 91 (45), 90 (33). Found: C, 80.71; H, $8.89 \%$. Calcd for $\mathrm{C}_{20} \mathrm{H}_{26} \mathrm{O}_{2}$ : C, $80.50 ; \mathrm{H}, 8.78 \%$.

Synthesis of 1',2',3',8a'-tetrahydrospiro[adamantane-2,1'azulen]-3'-one (13): A mixture of $400 \mathrm{mg}(1.34 \mathrm{mmol})$ of 12 in formic acid $(10 \mathrm{ml})$ and phosphoric acid $(10 \mathrm{ml})$ was heated at $90^{\circ} \mathrm{C}$ for $12 \mathrm{~h}$. Then the resultant dark brown mixture was poured into water, and was extracted with ether $(50 \mathrm{ml} \times 3)$. The combined organic layer was washed with a saturated $\mathrm{NaHCO}_{3}$ aqueous solution and brine, and then dried over anhydrous $\mathrm{MgSO}_{4}$. The solvent was removed under reduced pressure, and the residue was purified by column chromatography $\left(\mathrm{SiO}_{2}, 3 \%\right.$ ethyl acetate in hexane as eluent) to give $180 \mathrm{mg}$ ( $50 \%$ yield) of $\mathbf{1 3}$ as yellow microcrystals. $\mathrm{Mp}=117-118^{\circ} \mathrm{C} .{ }^{1} \mathrm{H}$ NMR $\left(\mathrm{CDCl}_{3}\right) \delta 1.54(\mathrm{~m}, 1 \mathrm{H})$, $1.60-1.88(\mathrm{~m}, 11 \mathrm{H}), 2.08(\mathrm{dm}, J=13.2 \mathrm{~Hz}, 1 \mathrm{H}), 2.20(\mathrm{~m}, 1 \mathrm{H})$, $2.31(\mathrm{~d}, J=5.2 \mathrm{~Hz}, 1 \mathrm{H}), 2.32(\mathrm{~d}, J=17.6 \mathrm{~Hz}, 1 \mathrm{H}), 2.89(\mathrm{~d}, J=$ $17.6 \mathrm{~Hz}, 1 \mathrm{H}), 5.58(\mathrm{dt}, J=9.2,5.2 \mathrm{~Hz}, 1 \mathrm{H}), 6.37(\mathrm{dd}, J=9.2,6.0$ $\mathrm{Hz}, 1 \mathrm{H}), 6.84$ (dd, $J=10.4,6.0 \mathrm{~Hz}, 1 \mathrm{H}), 6.93$ (dd, $J=10.4,6.0 \mathrm{~Hz}$, $1 \mathrm{H}), 6.99(\mathrm{~d}, J=6.0 \mathrm{~Hz}, 1 \mathrm{H}) \mathrm{ppm} ;{ }^{13} \mathrm{C} \mathrm{NMR}\left(\mathrm{CDCl}_{3}\right) 26.7,27.5$, $33.4,33.5,33.6,33.8,34.4,34.5,38.4,44.3,45.8,49.1,122.3$, 123.6, 126.2, 129.8, 130.4, 135.7, $203.3 \mathrm{ppm}$; UV (MeOH) $\lambda_{\max }=$ $223(\log \varepsilon=4.55), 232 \mathrm{sh}(4.00), 294$ (3.71), 317sh (3.65), 372sh $(2.88) \mathrm{nm}$; IR $(\mathrm{KBr}) v_{\max }=2909 \mathrm{~s}, 2855 \mathrm{~s}, 1701 \mathrm{~s}, 1617 \mathrm{~s}, 720 \mathrm{~s} \mathrm{~cm}^{-1}$; MS (70 eV) m/z (rel int) $266\left(\mathrm{M}^{+}, 12\right), 224$ (17), 118 (100), 90 (66). Found: C, 85.67; H, 8.56\%. Calcd for $\mathrm{C}_{19} \mathrm{H}_{22} \mathrm{O}: \mathrm{C}, 85.67 ; \mathrm{H}, 8.32 \%$.

Synthesis of tosylhydrazone of 13: A suspension of $13(100 \mathrm{mg}$, $0.376 \mathrm{mmol}), 70 \mathrm{mg}(0.38 \mathrm{mmol})$ tosylhydrazide, and $5 \mathrm{ml}$ of dry THF was stirred at $50^{\circ} \mathrm{C}$ for $96 \mathrm{~h}$. The solids formed were collected by filtration and washed well with ether to give $137 \mathrm{mg}$ of tosylhydrazone of $\mathbf{1 3}$ (84\% yield) as a yellow powder. Mp 189$193^{\circ} \mathrm{C} .{ }^{1} \mathrm{H}$ NMR $\left(\mathrm{CDCl}_{3}\right) \delta 1.26(\mathrm{~m}, 1 \mathrm{H}), 1.30(\mathrm{~m} 1 \mathrm{H}), 1.55-2.00$ $(\mathrm{m}, 12 \mathrm{H}), 2.09(\mathrm{~m}, 2 \mathrm{H}), 2.41(\mathrm{~s}, 3 \mathrm{H}), 3.04(\mathrm{~d}, J=16.8 \mathrm{~Hz}, 1 \mathrm{H})$, $5.32(\mathrm{dd}, J=10.1,5.2 \mathrm{~Hz}, 1 \mathrm{H}), 6.24(\mathrm{dd}, J=10.1,5.2 \mathrm{~Hz}, 1 \mathrm{H})$, $6.73(\mathrm{~m}, 2 \mathrm{H}), 6.88(\mathrm{~d}, J=5.6 \mathrm{~Hz}, 1 \mathrm{H}), 7.29(\mathrm{~d}, J=8.1 \mathrm{~Hz}, 2 \mathrm{H})$, $7.54(\mathrm{~s}, 1 \mathrm{H}), 7.85(\mathrm{~d}, J=8.1 \mathrm{~Hz}, 2 \mathrm{H}) \mathrm{ppm} ;{ }^{13} \mathrm{C} \mathrm{NMR}\left(\mathrm{CDCl}_{3}\right) 21.6$, 26.7, 27.4, 33.56, 33.64, 33.85, 33.89 (2C), 33.96, 34.3, 38.3, 46.7, 47.6, 118.0, 119.8, 125.7, 128.0, 129.6, 130.5, 131.0, 132.1, 135.4, 144.0, $157.5 \mathrm{ppm}$; IR (KBr) $v_{\max }=2909 \mathrm{~s}, 1162 \mathrm{~s} \mathrm{~cm}^{-1}$; MS $(70 \mathrm{eV})$ $\mathrm{m} / \mathrm{z}$ (rel int) $434\left(\mathrm{M}^{+}, 9\right), 297$ (100), 250 (65), 193 (16), 179 (14), 141 (19), 135 (34), 129 (25), 91 (57).Found: C, 71.88; H, 7.00; N, $6.49 \%$. Calcd for $\mathrm{C}_{26} \mathrm{H}_{30} \mathrm{~N}_{2} \mathrm{O}_{2} \mathrm{~S}: \mathrm{C}, 71.89 ; \mathrm{H}, 6.96 ; \mathrm{N}, 6.45 \%$.

Synthesis of 1',8a'-dihydrospiro[adamantane-2,1'-azulene] (14) : To a suspension of $200 \mathrm{mg}(0.461 \mathrm{mmol})$ of $\mathbf{1 6}$ in $20 \mathrm{ml}$ of dry ether at $0^{\circ} \mathrm{C}$ under nitrogen atmosphere, $2.2 \mathrm{ml}$ of methyl lithium solution ( $0.8 \mathrm{M}$ ether solution, $2.3 \mathrm{mmol}$ ) was added slowly using a syringe. After the addition, the mixture was stirred for $12 \mathrm{~h}$. The mixture was quenched by adding water carefully and was poured into a mixture of ether and ice-water. The aqueous layer was extracted with ether $(50 \mathrm{ml} \times 2)$. The combined organic layer was washed with brine and dried over anhydrous $\mathrm{MgSO}_{4}$. The solvent was removed under reduced pressure and the residue was purified by column chromatography $\left(\mathrm{SiO}_{2}\right.$, hexane as eluent) to give $13 \mathrm{mg}$ (11\% yield) of $\mathbf{1 4}$ as a pale yellow oil. ${ }^{1} \mathrm{H}$ NMR $\left(\mathrm{CDCl}_{3}\right) \delta 1.34(\mathrm{~m}, 1 \mathrm{H}), 1.56-1.93(\mathrm{~m}, 8 \mathrm{H}), 1.99(\mathrm{~m}, 2 \mathrm{H}), 2.09(\mathrm{tm}$ $J=10.6 \mathrm{~Hz}, 2 \mathrm{H}), 2.20(\mathrm{dm}, J=13.2 \mathrm{~Hz}, 1 \mathrm{H}), 2.35(\mathrm{~d}, J=5.0 \mathrm{~Hz}$, $1 \mathrm{H}, 8 \mathrm{a}-\mathrm{H}), 5.10(\mathrm{dd}, J=9.6,5.0 \mathrm{~Hz}, 1 \mathrm{H}, 8-\mathrm{H}), 6.04(\mathrm{~d}, J=5.6 \mathrm{~Hz}$, $1 \mathrm{H}, 2-\mathrm{H}), 6.11(\mathrm{dd}, J=10.8,5.6 \mathrm{~Hz}, 1 \mathrm{H}, 7-\mathrm{H}), 6.14(\mathrm{~d}, J=5.6 \mathrm{~Hz}$, $1 \mathrm{H}, 3-\mathrm{H}), 6.42(\mathrm{dd}, J=10.8,5.6 \mathrm{~Hz}, 1 \mathrm{H}, 6-\mathrm{H}), 6.60$ (dd, $J=10.8$, $5.6 \mathrm{~Hz}, 1 \mathrm{H}, 5-\mathrm{H}), 6.68(\mathrm{~d}, J=5.6 \mathrm{~Hz}, 1 \mathrm{H}, 4-\mathrm{H}) \mathrm{ppm} ;{ }^{13} \mathrm{C} \mathrm{NMR}$ $\left(\mathrm{CDCl}_{3}\right)$ 26.8, 27.8, 31.4, 32.5, 33.8, 34.90, 34.92, 38.3, 39.8, 49.0, 56.4, 114.0, 120.1, 124.2, 127.8, 129.1, 130.8, 144.6, 148.8 ppm; $\mathrm{UV}(\mathrm{MeOH}) \lambda_{\max }=229(\log \varepsilon=2.89), 234 \mathrm{sh}(2.89), 318$ (2.34) $\mathrm{nm}$; IR (KBr) $v_{\max }=3050 \mathrm{w}, 3017 \mathrm{~m}, 2908 \mathrm{vs}, 2856 \mathrm{~s}, 1623 \mathrm{~m}, 1455 \mathrm{~s}$, $704 \mathrm{~s} \mathrm{~cm}^{-1}$; MS (70 eV) m/z (rel int) $250\left(\mathrm{M}^{+}, 100\right), 193(20), 179$ (18), 154 (32), 135 (63), 128 (42), 115 (18), 91 (17). Found: 250.1722. Calcd for $\mathrm{C}_{19} \mathrm{H}_{22}$ : M, 250.1723 .

Synthesis of 1 ' $H$-spiro[adamantane-2,1'-azulenium] perchlorate (10): To a solution of $101 \mathrm{mg}(0.404 \mathrm{mmol})$ of $\mathbf{1 4}$ in 5 $\mathrm{ml}$ of acetonitrile under nitrogen atmosphere was added $134 \mathrm{mg}$ $(1.00 \mathrm{mmol})$ of trityl perchloratein in one portion. The mixture was stirred at $55^{\circ} \mathrm{C}$ for $17 \mathrm{~h}$. The solvent was removed under reduced pressure, and the residue was dissolved in the least amount of dichloromethane. Ether was added to the solution, and solids 
formed were collected and washed well with cold ether to give 90 $\mathrm{mg}$ of perchlorate salt of $\mathbf{1 0}$ as yellowish brown crystals. Mp $180{ }^{\circ} \mathrm{C}$ (dec.). ${ }^{1} \mathrm{H}$ NMR $\left(\mathrm{CD}_{3} \mathrm{CN}\right) \delta \tilde{1} 72(\mathrm{~m}, 2 \mathrm{H}), 1.92-2.30(\mathrm{~m}$, $8 \mathrm{H}), 2.47(\mathrm{dm}, J=14.0 \mathrm{~Hz}, 2 \mathrm{H}), 2.72(\mathrm{dm}, J=14.0 \mathrm{~Hz}, 2 \mathrm{H}), 7.47$ $(\mathrm{d}, J=6.0 \mathrm{~Hz}, 1 \mathrm{H}), 8.53(\mathrm{~d}, J=6.0 \mathrm{~Hz}, 1 \mathrm{H}), 8.74(\mathrm{~m}, 2 \mathrm{H}), 8.86(\mathrm{t}$, $J=10.6 \mathrm{~Hz}, 1 \mathrm{H}), 8.94(\mathrm{~d}, J=10.6 \mathrm{~Hz}, 1 \mathrm{H}), 9.72(\mathrm{~d}, J=10.6 \mathrm{~Hz}$, $1 \mathrm{H}) \sim \quad \sim \mathrm{ppm}_{\sim} \quad \sim \quad{ }_{\sim}^{13} \mathrm{C} \quad \mathrm{NMR} \quad\left(\mathrm{CD}_{3} \mathrm{CN}\right)$

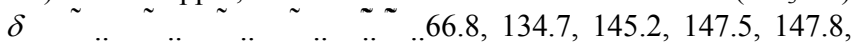
$149.4, \ddot{1} 53.1,168 . \ddot{7}, 171.7, \ddot{177.1} \mathrm{ppm} ; \mathrm{UV}\left(\mathrm{CH}_{3} \mathrm{CN}\right) \lambda_{\max }=224$ $(\log \varepsilon=3.17), 246$ (3.09), 280sh (3.65), 367 (2.91) nm; IR (KBr) $v_{\max }=2917 \mathrm{~s}, 1443 \mathrm{~s}, 1073 \mathrm{~s} \mathrm{~cm}^{-1} ; \mathrm{MS}(70 \mathrm{eV}) \mathrm{m} / \mathrm{z}$ (rel int) 249 $\left(\mathrm{C}_{19} \mathrm{H}_{21}{ }^{+}, 22\right), 248$ (100), 205 (19), 193 (11), 191 (52), 179 (24), 165 (23), 152 (12), 141 (10). Found: C, 63.27; H, 6.01\%. Calcd for $\mathrm{C}_{19} \mathrm{H}_{21} \mathrm{ClO}_{4} \cdot 0.2 \mathrm{CH}_{2} \mathrm{Cl}_{2}$ : C, 63.04; H, 5.90\%.

X-ray crystallographic analysis of 10: One crystal having approximate dimensions of $0.40 \times 0.30 \times 0.50 \mathrm{~mm}$ was mounted on a glass fiber. All measurements were conducted using a Rigaku AFC7R diffractometer with graphite monochromated Mo-Ka radiation and a rotating anode generator. Cell constants and an orientation matrix for data collection, obtained from a least-squares refinement using the setting angles of 25 carefully centered reflections in the range $25.45<2 \theta<29.46^{\circ}$, corresponded to a primitive monoclinic cell with dimensions: $a=7.439$ (2) $\AA, b=$ 17.479 (4) $\AA, c=12.878$ (1) $\AA, \beta=92.52$ (1) ${ }^{\circ}, V=1672.9$ (4) $\AA^{3}$. For $Z=4$ and formula weight $=348.83$, the calculated density was $1.38 \mathrm{~g} \mathrm{~cm}^{-3}$. Based on a statistical analysis of the intensity distribution and the successful solution and refinement of the structure, the space group was uniquely determined to be $P 2_{1} / \mathrm{c}$ (\# 14). The data were collected at a temperature of $23 \pm 1^{\circ} \mathrm{C}$ using the $\omega-2 \theta$ scan technique to a maximum $2 \theta$ value of $60.0^{\circ}$. Omega scans of several intense reflections, made prior to data collection, had an average width at a half-height of $0.26^{\circ}$ with a take-off angle of $6.0^{\circ}$. Scans of $(1.73+0.30 \tan \theta)^{\circ}$ were made at speeds of $8.0^{\circ}$ $\min ^{-1}$ (in omega). The weak reflections $(I<10.0 \sigma(I))$ were rescanned (maximum of 5 scans) and the counts were accumulated to ensure good counting statistics. Stationary background counts were recorded on each side of the reflection. The ratio of peak counting time to background counting time was $2: 1$. The diameter of the incident beam collimator was $0.5 \mathrm{~mm}$, and the crystal-todetector distance was $235 \mathrm{~mm}$. The computer-controlled slits were set to $3.0 \mathrm{~mm}$ (horizontal) and $5.0 \mathrm{~mm}$ (vertical). Of the 5396 reflections collected, 4891 were unique $\left(\mathrm{R}_{\text {int }}=0.028\right)$. The intensities of three representative reflections were measured after every 150 reflections. No decay correction was applied. The linear absorption coefficient $\mu$ for Mo-K $\alpha$ radiation is $2.5 \mathrm{~cm}^{-1}$. Azimuthal scans of several reflections indicated no need for an absorption correction. The structure was solved by direct methods and expanded using Fourier techniques. The non-hydrogen atoms were refined anisotropically. Hydrogen atoms were included but not refined. The final cycle of full-matrix least-squares refinement was based on 4891 observed reflections $(I>-10.00 \sigma(I))$ and 217 variable parameters, and they converged (largest parameter shift was 0.00 times its esd) with unweighted and weighted agreement factors: $R=0.120, R w=0.211$, and $R 1=0.072$ for $I>2.0 \sigma(I)$ data. The standard deviation of an observation of unit weight was 1.05 . The weighting scheme was based on counting statistics and included a factor $(\mathrm{p}=0.050)$ to downweight the intense reflections. Plots of $\Sigma w(|F o|-|F C|)^{2}$ versus $|F o|$, reflection order in data collection, $\sin \theta / \lambda$, and various classes of indices showed no unusual trends. The maximum and minimum peaks on the final difference Fourier map corresponded to 0.98 and $-0.71 \mathrm{e}^{-} / \AA^{3}$, respectively. Tables of fractional atomic coordinates, thermal parameters, bond lengths, and angles have been deposited at the Cambridge Crystallographic Data Centre, 12 Union Road, Cambridge CB2 1EZ, United Kingdom (CCDC 677990).
Cyclic voltammetry: A standard three-electrode cell configuration was employed using a glassy carbon disk working electrode, a Pt wire auxiliary electrode, and an $\mathrm{Ag}$ wire as an $\mathrm{Ag} / \mathrm{Ag}+$ quasireference electrode. The reference electrode was calibrated at the completion of each measurement on a saturated calomel electrode (SCE). Cyclic voltammetry was measured in an acetonitrile solution with tetrabutylammonium perchlorate as supporting electrolyte at a scan rate of $0.1 \mathrm{Vs}^{-1}$ at $25^{\circ} \mathrm{C}$. Under these conditions, ferrocene showed a half-wave oxidation potential of $+0.40 \mathrm{~V}$ vs SCE.

\section{Acknowledgments}

We gratefully thank Takao Ike-uchi and Hitoshi Kainuma at the University of Toyama for their preliminary synthetic efforts. This study was supported by a Grant-in-Aid for Scientific Research (No. 13640528 to M.O.) from the Ministry of Education, Science, Technology, Sports and Culture, Japan and also by a research grant from the Faculty of Science at Shinshu University.

[1] a) W. v. E. Doering, L. H. Knox, J. Am. Chem. Soc. 1954, 76, 32033206 ; b) W. v. E. Doering, L. H. Knox, J. Am. Chem. Soc. 1957, 79, 3203-3206.

[2] For reviews on the tropylium cation, see; a) F. Pietra, Chem. Rev. 1973, 77, 293-364; b) T. Asao, M. Oda, Methoden Der Organischen Chemie, (Houben-Weyl), Bd.5, 2c; Carbocyclische $\pi$-ElektronenSysteme, (Ed.: Kropf, H.), Georg Thieme Verlag, Stuttgart, 1986, pp. 49-85.

[3] a) M. Oda, A. Sakamoto, T. Uchiyama, T. Kajioka, R. Miyatake, S Kuroda, Tetrahedron Lett. 1999, 40, 3595-3596; b) M. Oda, A. Fukuta, T. Kajioka, T. Uchiyama, R. Miyatake, S. Kuroda, Tetrahedron 2000, 56, 9917-9925; c) M. Oda, A. Fukuta, T. Uchiyama, T. Kajioka, S. Kuroda, Recent Research Developments in Organic Chemistry Vol. 6; Transworld Research Network, Trivandrum, 2002, Vol. 6, pp. 543-563; d) M. Oda, H. Kainuma, R. Miyatake, S. Kuroda, Tetrahedron Lett. 2002, 43, 3485-3488; e) M. Oda, H. Kainuma, T. Uchiyama, R. Miyatake, S. Kuroda, Tetrahedron 2003, 59, 2831-2841.

[4] For our related carbocations with smaller rings, see; a) M. Oda, T Kajioka, T. Okujima, S. Itoh, N. Morita, R. Miyatake, S. Kuroda, Chem. Lett. 1997, 1011-1012; b) M. Oda, T. Kajioka, T. Okujima, T. Uchiyama, K. Nagara, S. Itoh, N. Morita, T. Sato, R. Miyatake, S. Kuroda, Tetrahedron 1999, 55, 6081-6096; c) M. Oda, T. Kajioka, Y. Kawamori, T. Uchiyama, S. Kuroda, N. Morita, Recent Research Developments in Organic \& Bioorganic Chemistry, Vol. 4; Transworld Research Network, Trivandrum, 2001, Vol. 4, pp. 133149; d) M. Oda, A. Sakamoto, R. Miyatake, S. Kuroda, Tetrahedron Lett. 1998, 39, 6195-6198; e) M. Oda, A. Sakamoto, T. Kajioka, R. Miyatake, S. Kuroda, Tetrahedron 1999, 55, 12479-12492.

[5] M. Oda, N. Nakajima, N. C. Thanh, T. Kajioka, S. Kuroda, Tetrahedron 2006, 62, 8177-8183.

[6] K. Komatsu, K. Takeuchi, M. Arima, Y. Waki, S. Shirai, K. Okamoto, Bull. Chem. Soc. Jpn. 1982, 55, 3257-3261.

[7] M. Oda, T. Kajioka, K. Ikeshima, R. Miyatake, S. Kuroda, Synth. Commun. 2000, 30, 2335-2343.

[8] S. Murata, M. Suzuki, R. Noyori, Tetrahedron Lett. 1980, 21, 25272528.

[9] For recent reviews of the Nazarov cyclizations, see; a) M. A. Tius, Eur. J. Org. Chem. 2005, 2193-2206; b) H. Pellissier, Tetrahedron 2005, 61, 6479-6517; c) A. J. Frontier, C. Collison, Tetrahedron 2005, 61, 7577-7606.

[10] For our recent results for preparing tetrahydroazulen-1-ones by the Nazarov cyclization, see; a) M. Oda, T. Yamazaki, T. Kajioka, R. Miyatake, S. Kuroda, Liebigs Ann./Recueil 1997, 2563-2566; b) T. Kajioka, M. Oda, S. Yamada, R. Miyatake, S. Kuroda, Synthesis 1999, 184-187; c) M. Oda, T. Kajioka, K. Haramoto, R. Miyatake, S. Kuroda, Synthesis 1999, 1349-1353.

[11] R. H. Shapiro, Org. React. 1976, 23, 405-507. 
[12] a) S. Winstein, P. Carter, F. A. L. Anet, A. J. R. Bourn, J. Am. Chem. Soc. 1965, 87, 5247-5249; b) F. A. L. Anet, A. J. R. Bourn, P. Carter, S. Winstein, J. Am. Chem. Soc. 1965, 87, 5249-5250; c) T. H. Regan, J. B. Miller, J. Org. Chem. 1967, 32, 2789-2793; d) B. V. Cheney, J. Am. Chem. Soc. 1968, 90, 5386-5390; e) M. A. Cooper, S. L. Manatt, J. Am. Chem. Soc. 1970, 92, 4646-4652.

[13] For mechanistic studies on the Nazarov cyclization, see the following and the studies cited there; a) W. He, W. Ildiko, T. A. Atesin, P. A. Caruana, C. A. Kellenberger, A. J. Frontier, J. Am. Chem. Soc. 2008, 130, 1003-10011; b) V. Polo, J. Andrés, J. Chem. Theory Comput. 2007, 3, 816-823.

[14] DFT calculations were conducted using the PC GAMESS version $[14 \mathrm{a}, 14 \mathrm{~b}]$ of the GAMESS (US) QC package [14c]. Structures were optimized at B3LYP/6-31G(d) level of theory; a) A. A. Granovsky, PC GAMESS version 7.1: http://classic.chem.msu.su/gran/gamess/index.html; b) A. V. Nemukhin, B. L. Grigorenko, A. A. Granovsky, Molecular modeling by using the PC GAMESS program: From diatomic molecules to enzymes Moscow Univ. Chem. Bull. 2004, 45, 75; c) M. W. Schmidt, K. K. Baldridge, J. A. Boatz, S. T. Elbert, M. S. Gordon, J. H. Jensen, S. Koseki, N. Matsunaga, K. A. Nguyen, S. Su, T. L. Windus, M. Dupuis, J. A. Montgomery Jr., J. Comput. Chem. 1993, 14, 13471363.
[15] For linear relationships between thermodynamic and kinetic parameters of aromatic carbocations, see; K. Okamoto, K. Takeuchi, K. Komatsu, Y. Kubota, R. Ohara, M. Arima, K. Takahashi, Y. Waki, S. Shirai, Tetrahedron 1983, 39, 4011-4024.

[16] H. J. Dauben, Jr., R. Lewis, R. Honnen, K. M. Harman, J. Org. Chem. 1960, 25, 1442-1445.

[17] E. Nakamura, K. Hashimoto, I. Kuwajima, J. Org. Chem. 1977, 42, 4166-4167.

[18] a) K. Komatsu, H. Akamatsu, Y. Jinbu, K. Okamoto, J. Am. Chem. Soc. 1988, 110, 633-634; b) K. Komatsu, H. Akamatsu, S. Aonuma, Y. Jinbu, N. Maekawa, K. Takeuchi, Tetrahedron 1991, 47, 69516966.

Received: ((will be filled in by the editorial staff)) Published online: ((will be filled in by the editorial staff)) 
Entry for the Table of Contents (Please choose one layout)

\section{Layout 1:}

((Key Topic))

((Text for Table of Contents - max. 350 characters))

((Please adjust TOC Graphic to the size of this area; max. width $5.5 \mathrm{~cm}$ ))

\section{Layout 2:}

((Stable Carbocation))

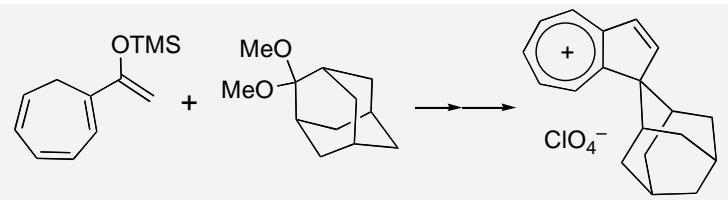

The $\mathrm{p} K_{\mathrm{R}}+$ value of the title cation was found to be 9.8 , which is less than that expected by inductive stabilization of the carbon number at the 1-position.
The X-ray crystal structure of the title cation $\left(\mathrm{ClO}_{4}^{-}\right.$salt $)$reveals $\mathrm{CH}-\mathrm{O}$ interactions and deformation of the azulenyl ion part.
Mitsunori Oda, * Nobue Nakajima, Nguyen Chung Thanh, Kazuhiro Kitahara, Ryuta Miyatake, and Shigeyasu Kuroda...Page No. - Page No.

Synthesis, stability, and crystal structure of an azulenium cation containing an adamantyl group

Keywords: Carbocations / Spiro compounds / Nazarov cyclizations / 